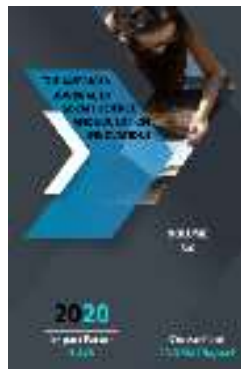

\title{
Synergetic Aspects Of The Historical And Cultural Fundamentals Of The Development Of Confessional And Philosophical Doctrine In Central Asia
}

\author{
Evatov Salimjon Sobirovich \\ Lecturer At The Department Of Civil Society, Fergana State University, Uzbekistan
}

Journal Website:

http://usajournalshub.c

om/index,php/tajssei

Copyright: Original

content from this work

may be used under the

terms of the creative

commons attributes

4.0 licence.

\section{ABSTRACT}

The article analyzes the emergence of mystical and philosophical doctrines in Central Asia, their stages of development, the content and essence of the ideas put forward in them. The article also analyses the history of synergetic aspects of the relationship between orthodox Islam and mysticism in Central Asia, based on the analysis of the socio-economic, political and spiritual-cultural reasons for the formation of sects in Central Asia.

\section{KEYWORDS}

Religion, Islam, mysticism, philosophy, Eastern philosophy, doctrine, teachings, ideas, recluse, Sufi life.

\section{INTRODUCTION}

During the years of independence, the development of the sacred religion of Islam, as well as the study of the advanced ideas of mysticism, which emerged at its core, was established. A new stage of further deepening of democratic processes has begun in Uzbekistan, and in recent years the Government of the Republic of Uzbekistan has signed and implemented a number of important documents in the field of religion. In particular, the Islamic Academy of Uzbekistan and the International Center of Islamic Culture have been established and started working process. There is a school of mysticism in Bukhara. The anniversaries of famous Sufis such as Bahauddin Nakshband, Khoja Ahror Vali, Najmiddin Kubro, Abdukholiq Gijduvani were celebrated. Many works from the 
scientific works of the great representatives of mystical teachings have been published.

In all democracies of the world, citizens have the right to freedom of conscience. Therefore, the development of religious relations, strengthening the interaction of different faiths, the development of public authorities, civil society institutions, public and nongovernmental organizations, further raising the morale of citizens, ensuring interfaith harmony in a multi-religious environment, a comprehensively mature man the study of the problems of personality creation is one of the most important issues in the science of philosophy. The world community supports the achievements in addressing the development of religious tolerance in a multiethnic Uzbekistan on the basis of consensus, in-depth analysis of the interests and needs of different nationalities and finding scientific solutions to existing problems. These are the great works on the study of the history of our people during the years of independence, "the restoration of our sacred religion, our national values, the memory of our great saints, their heritage, the beautification of their monuments" [1]. Continuing his conclusion that the 72nd session of the UN General Assembly "is an important task to convey the true human nature of Islam to the world community" [2], in his address to the Oliy Majlis, the President gave priority to ensuring religious tolerance [3].

\section{MATERIALS AND METHODS}

Works and research on mysticism can be divided into several groups: the first group includes works that describe the mystical views and experiences of mystics. Yassavi's "Hikmatlar", Imam Abu Hamid Ghazzali's "Ihyou ulumad-din", Najmiddin Kubro's "Usuliashara”, Hakim Termizi's “Manozil ulibad min al-iboda', Aziziddin Nasafi's "Zubdat ul-haqayiq", Jalaliddin Rum's "Masnavii Manavii”, Fariduddin Attor's "Asrornoma", "Tazkiratal-avliyo", Abdukholiq Gijduvani's "Vasiyatnoma"[4] are valuable sources on the history and theory of mysticism. The second group includes works that study the teachings of mysticism from the point of view of Islam, the science of belief, and theology. This includes Ibn Arabi's Fusus al-Hikam, al-Futuhot al-Makkiya, and M.A. Jushan's Islam, Sufism, and Morality. The third group includes works that study the teachings of mysticism in terms of modern scientific-philosophical, artisticaesthetic, historical, spiritual-enlightenment heritage. Among these works are foreign DJ Trimmingham, R. Nicholson, U. Turar, AD Knysh, JA Subkhan, IM Filshtinsky, Uzbek scientists M. Boltaev, M. Khairullaev, N. Kamilov. mystical and irrational aspects of mysticism, E. Karimov the stages of development of the history of mysticism in Central Asia, R. Shodiev the religious and epistemological essence of mysticism in Central Asia, N. Safarova the history of formation of Khojagon mysticism in Central Asia and the epistemological and philosophical views of the seven elders. Navruzova Bahouddin Naqshband's philosophical views on the perfect man, O.Sharipova Abdulkholiq Gijduvani's mystical views, E.Zoirov Makhdumi Azam's socio-political views, G.Yunusova Abdulkadir Gilani's views on the world in their research they shed light on scientific views and ideas, as well as developed suggestions and recommendations. Sheikh Muhammad Sadiq Muhammad Yusuf [6] in his works revealed the essence of mysticism in purifying the human heart and improving its spirituality. These studies focus on mystical schools, sects and the mystical views of individual mystics, and serve as a methodological source for understanding scientific and philosophical ideas in the study of the problem within the subject. However, they 
do not aim to reveal the historical and philosophical essence of mystical teachings.

\section{RESEARCH METHODOLOGY}

In the course of the research were used scientifically-philosophical principles and methods such as systematics, theoreticaldeductive conclusions, analysis and synthesis, history and logic, hermeneutic analysis, inheritance, universalism and nationality, comparative analysis.

\section{ANALYSIS AND RESULTS}

The role and importance of Islamic knowledge in understanding the traditions of formation and development of the spirituality and culture of the peoples of Central Asia is incomparable. In this regard, it is impossible to know the qualitative changes of Eastern social development, especially without knowing the essence of mysticism. Islamic mysticism has its own history, process of formation and improvement, and the historical and cultural foundations of its development are also distinguished by their specificity.

Turkish mystic Kamil Yilmaz in his book "Sufism and sects" describes the practical and theoretical, as well as spiritual and experimental features of mysticism.

- Since mysticism is a science that is studied in practice, the side of a murshid is studied in the presence of a teacher called a sheikh.

- Sufism is the science of the state, which is felt, lived and understood through experience.

- The subject of the science of tasavvuf is marifatullah.

- Sufism is not a biblical science. (In the sense that it is not a science to learn from a book)

- It is a science beyond reason.

- Sufism deals not only with the visible world, but also with the unseen world.
- Sufism is introduced through a way called sect.[7]

The influence of various mythological religious and philosophical ideas that emerged on this soil is strong in the formation, development and beauty of mystical-philosophical ideas in Central Asia. For example, ideas such as the creation of the Zoroastrian world, the writing of sins, the reward of the afterlife, heaven and hell, the coming of a bridge, and the coming of a savior after death, which had been believed by the people for centuries, were fully reflected in Islam. But the main idea of Zoroastrianism was the eternal and uncompromising struggle between nature and society, good and evil in the human heart, in which the doctrine that those who follow the rules of Ahuramazda fight evil to decide goodness and ultimately win paved the way for intellectual development. The development of science was an expression of goodness. That is why secular sciences were taught in all preIslamic Zoroastrian temples, and devotion to it was strong.

In fact, what is meant by mystical-philosophical teachings. It is also worthwhile to find answers to the question of what doctrines can be included in mystical-philosophical teachings and in what way they can be classified. The mystical-philosophical concept is not just a phrase that signifies a common feature in one direction. This expression refers to the study of certain issues in the universe and man, nature and society within the framework of philosophy and mysticism, and the disappearance of clear boundaries and gradual harmonization with each other in problem analysis and methodology. For example, the contradictions between the Mutazilites and the Mutakkallimin in Islamic philosophy, or the disputes over the existence of the possible and the obligatory, and the teachings on which they are based, are called mystical- 
philosophical teachings. Thinkers who debate and conduct research within the framework of these teachings can also be described as mystical and philosophical scholars.

It is known that the leading direction of Eastern philosophy is aimed at purifying the human heart and soul, creating in it the qualities of a perfect human being, and on this basis the humanization of social relations. The idea that spiritual wealth, moral purity, honesty, and integrity are important conditions for the transformation of a person into a human being, rather than a fleeting world or a career, led to the formation and spread of mysticism in the East.

Under the influence of the Mu'tazilites, who are considered to be mystical and philosophical doctrines, their existence in Islam is possible and their existence is formed by the obligatory currents. Representatives of the possible scholars of existence include Al-Kindi, Ibn Rushd, Al-Maarri, Farobi, Ibn Sina, and Umar Khayyam. The body has a possible cause-andeffect relationship, and its existence stems from its essence, not from anything else. Such an approach opens the way for the development of science, allowing the explanation of natural phenomena on the basis of independent internal causes. The ideological struggles between the Mu'tazilites and the Mutakallimun were formed when the word of Abu Hamid al-Ghazali was formed and Islamic philosophy emerged. Although Abu Hamid alGhazali was initially inclined to Sufi views, he later created his own word based on a critique of their teachings. However, he unwittingly justifies mysticism theoretically.

The historical and cultural foundations of the development of mystical and philosophical teachings in Central Asia are also known from the place of origin of Sufism and its essence, as well as from the goals and tasks assigned to it.
In general, there are various theories about the origin of mysticism, one of which is the approach given in the History of Iran by the orientalist Comte de Gobinho causes that this approach was later approved by Brown and was not criticized by several German scholars.

The contribution of the children of Central Asia in the development of mysticism was invaluable. Hodja Hakim at-Termizi, Hodja Abdukhaliq Gijduvani, Hodja Ahmad Yassavi, Suleiman Baqirgani, Sheikh Najmiddin Kubro, Hodja Ali Romitani, Abu Ali al-Farmadi, Yusuf Hamadoni, Bahauddin Naqshband became the leaders of the path of divine enlightenment. The doctrines they created and the spiritual and moral ideas they put forward have not lost their relevance even today.

The analysis of the historical and cultural foundations of the development of mystical and philosophical teachings in Central Asia showed that the formation and development of mystical philosophy and mystical teachings played an important role in the formation of sects and their traditions here.

The cultural basis of the development of mystical and philosophical teachings in Central Asia is a large part of the spiritual heritage and sacred values of the peoples, Islamic spirituality and national traditions and customs. The sources of religious values are reflected in the Kuran, Hadiths, commentaries, and Shari'a rules. An important part of our Islamic heritage is the mystical teachings and values of mysticism, in particular, the three great mystical sects: Yassavia, Kubroviya and Khojaganiya-Naqshbandiya, which formed in Central Asia and have now made a significant contribution to the development of world spiritual culture and universal values. sects.

In the Hijri 3rd and 4th centuries, along with ascetic life, there was a process of going from the outward to the inward. That is, the idea of 
spiritual purification and attainment of God became the basic idea. As a result, mystics began to look for ways of human spiritual perfection in various ways. During this period, the Islamic conception was formed as a science and its own principles were established. It was a time when great mystics began to arrive and classical mystical works were written. Sufis began to take shape as an independent class in society. Great mystics from Central Asia also emerged during this period and made a significant contribution to the development of mysticism. Among the great mystics of this period were Mansur Khallaj, Maruf Krkhi, Zunun Misri, Boyazid Bistomi, Sirri Saqiti, Junayd Baghdadi, Sahl ibn Abdullah Tustari, Abul Husayn Nuri, Shibli. Also during this period, the largest schools of mysticism in Basra, Bufa, Baghdad, Egypt, Medina and Khorasan were formed and established their own path. Another peculiarity of this period was that the mystics of Central Asia considered the mystical views prevailing in Iraq to be "formal" and lived in the heart without revealing the mysticism, and stressed that the main task of man is to reform the nafs, abstain from hypocrisy and tie the heart to God alone. those who gave.

Although the period of the first formation of mystical teachings coincides with the period of the first Islam, the period of full formation was formed and decided on the basis of sociopolitical, spiritual and religious mystical ideas and teachings that existed as a whole doctrine until the XIII century. During this period, the development of mysticism as a whole doctrine, formed under the influence of fire-worship, Buddhism, ancient Greek philosophy and religious ideas in Christianity, became necessary in harmony with Islamic teachings and ideas. That is, on the basis of Islamic teachings, mysticism formed and regulated its own beliefs, and in the IX-X centuries it became a doctrine of a unified system [8].
The penetration of mysticism into Central Asia is associated with Yusuf Hamadoni, and his contribution to its spread was great. Four famous Sufi scholars, Abdullah Barqi, Khoja Hasan Andoqi, Khoja Ahmad Yassavi, and Abdukholiq Gijduvani, emerged from his school, which was the basis for the spread of Sufism in Movarounnahr. Also, the influence of hadith scholars and religious scholars on the formation and development of mystical teachings in the Islamic world was great. The works of Imam Bukhari, Al-Hakim at-Termizi, alZamahshari, Marghinani served as the basis both theoretically and practically.

Growing up in Central Asia, the creative activities of Ahmad Yassavi, Najmiddin Kubro, Bahauddin Naqshband lay the foundation for the world-famous sects of mysticism. The sects founded by them will have a place in social development in harmony with the teachings of Islam.

The Yassaviya sect has a place in the development of mystical ideas in Central Asia. Its formation dates back to the Karakhanid period. This period was a period in which Central Asia achieved great heights in world development. In natural sciences: astronomy, cosmology and astronomy, mathematics, chemistry, medicine, biology, geology, geography, geodesy and other sciences, in social sciences: language and literature, history, philosophy, logic, law, theology of Kuran, Sharia jurisprudence The "Golden Age" of the Islamic world came to Samarkand from Baghdad. It was a time when science in all fields had risen to the level of science. Musa Khorezmi (died 850), Ahmad Fergani (died 865), Abu Mansur Moturidi (died 944). It was a period of scientific progress created by Abu Nasr al-Farabi (died 950) and dozens and hundreds of other scholars. The sciences of Abu Ali ibn Sina (died 1037) and Abu Rayhan alBiruni (died 1048) amazed the world. Ahmad 
Yassavi was a contemporary of such famous scholars as Ibn Sina, Beruni, Mahmud Kashgari, Yusuf Khas Hajib. Thus, Central Asia was a period in which the development of science was a major pillar of world civilization.

Ahmad, who was born at such a time, was a great grace of Allah to the peoples of Turan, to mankind in general. It was a requirement of that time for Ahmad Yassavi to have a certain teaching for the people of the region and to guide the people to the right path. Because it was a time when the influences of the various religions that existed among the local peoples had almost disappeared. It is known that the conversion of nomadic tribes to Islam was also on the agenda of that period. It was at this time that Ahmad Yassavi was born on the property of Turkestan, one of the sites of ancient culture.[9]

Although the Yassavi sect founded by Ahmad Yassavi differs from other sects in mysticism in terms of etiquette and archon, it is essentially no different from them. The distinguishing feature of the form is in its language. In the Yassaviya sect, the ideas of Islamic mysticism were first interpreted in Turkish. Another unique and important aspect of Yassavi is that he did not deviate from Turkish morals, ancient Turkic worldviews and beliefs, as well as the creative use of Persian mystical practices as the main source of Islam and its main book, the Kuran.[10]

The cultural foundations of the Yassaviya sect go back to Islamic philosophy and ancient world philosophy. As in all sects, the Yassaviya sect deals with the issues of soul and spirit, its interpretation, and in this respect, the Yassaviya sect differs from other sects. The rules of the Yassaviya sect are set out in Ahmad Yassavi's Wisdom, in which a person can attain the vision of Allah by living with compassion, honesty, and honest work. Again, he did not try to accumulate wealth, but lived in poverty. Ahmad Yassavi, who followed the path of enlightenment, will have a worthy place in the history of mysticism. He is called "Sultan-ulArif" or the Sultan of the Arifs. As a true sage, Yassavi entered the path of poverty at a very young age. [11]

In general, the doctrine of mysticism, in a sense, is the doctrine of prophethood and devotion to enlightenment. In this regard, Junaid Baghdadi's foundations of mysticism are the generosity of Abraham [11], the submission of Ishmael, the patience of Job, the silence of the Prophet Zikriya, the strangeness of John, the abandonment of Jesus, and the poverty of Muhammad Mustafa.

It is known from history that many scholars, scholars, poets and poetesses grew up in the land called Movaraunnahr or Turkestan. Abu Ali ibn Sina, Abu Rayhan Beruni, Abu Bakr Razi, Musa al-Khwarizmi, Ahmad Fergani, Imam alBukhari, al-Termizi, az Zamakhshari, Bahauddin Naqshband were among the scholars who had a significant impact on the development of mystical and philosophical ideas in Central Asia. Najmiddin Kubro, Zangi Ota, Khoja Ahrori Wali, Mahdumi Azam, Abdukholiq Gijduvani can be included.

It is known that the Khojagan sect prevailed in Central Asia, and its spread began mainly with Khoja Yusuf Hamadoni. His activities were continued by his students Barraqi, Andoqi, Gijduvani and Yassavi [12]. It is also expedient to study the mystical ideas of Barraqi and Andaki through modern research.

The Naqshbandi sect was also formed from Central Asia, and several perfect representatives of this path emerged. The main ring of the Naqshbandi sect - the main series - contains the names of eleven leaders who worked in our country and whose graves are on this land. In the study of the history of 
mysticism, the life and activities, thoughts and views of this eleven nobles have been extensively analyzed. The graves of seven of them are in Bukhara, one in Surkhandarya, one in Samarkand and two in Kashkadarya. Gijduvani, a great representative of the Naqshbandi sect, tried to spread knowledge and enlightenment, to bring up a perfect man, to make a living by manual labor, and to avoid the haram. He was born in 1103 in Gijduvan. He studied first in Gijduvan, then in Bukhara. At the age of 22, he met in Bukhara the great scholar and mystic of that time, the founder of the Khojagon sect, Khoja Yusuf Hamadoni, and mastered the methods of the Khojagan sect. Soon he became a great mystic.

It is known that one of the mystical sects formed in Central Asia is Sheikh Najmiddin Kubro, the founder of the Kubroviya Way. After a thorough study of the religious sciences and the science of hadith, Rozbihan Vazzah became a murid in Egypt. After strict math, he was sent to Khorezm by the sheikh on the mission of irshad after gaining the attention of the murshid. The book "Usuli Ashara" written by Najmiddin Kubro has influenced the development of all religions. In particular, many studies have been conducted on the influence of the Mavlavi and Naqshbandi sects. This method, which is a characteristic of this sect, is based on the fact that it came from Khazrat Ali.

Najmiddin Kubro was not only a mystical scholar who had a place in the history of mysticism, but also focused on the study of secular sciences. First of all, he traveled to distant lands and managed to study secular sciences along with religious, divine, and cultural sciences. He was not only the founder of the sect, but also a great sheikh, a great sage, a true patriot and a patriot. He was famous for rescuing ordinary people from oppression, doing good deeds, and sacrificing his life for the motherland.

\section{CONCLUSION}

In conclusion, the creation of a favorable social environment for the formation and development of mystical and philosophical teachings in Central Asia, the high social need for the study of philosophical sciences, as well as the improvement of rational-emotional knowledge in understanding Islam and its environment are the main factors of great mysticism and widespread mystical teachings. was The main mystical ways formed in the Middle Ages also had a significant positive impact on social development by encouraging the people of the region to enlightenment, understanding the Creator and spiritual connection with him, moral maturity. As a result, under the influence of mysticalphilosophical ideas and teachings, people's thinking, worldview, way of believing and ways of connecting with God, and the spiritual environment in general, become more beautiful. Therefore, it will be possible to raise the spiritual and cultural development of our society to a new level through the development of research on the source, the discovery of the essence of mystical and philosophical teachings in Central Asia.

\section{REFERENCES}

1. Mirziyoev Sh.M. Let us be more united and work resolutely for the fate and future of our country. Speech at the conference "Ensuring social stability, maintaining the purity of our sacred religion - the need of the hour." /Hidoyat, -Tashkent. 2017. -№ Page 6. 7

2. Mirziyoev Sh.M. Speech at the 72 nd session of the United Nations General Assembly. /Khalk sozi, -Tashkent, 2017. September 20. 
3. Address of the President of the Republic of Uzbekistan Sh.M.Mirziev to the Oliy Majlis. / Khalk sozi, Tashkent. 2017. -№ 258 (6952).

4. Gijduvoniy A. Vasiyatnoma/ -Tashkent: Literature and art, 1993.

5. Joshon M.A. Islam, mysticism and ethics. Tashkent: Istiqlol, 2000.

6. Muhammad Sadiq Muhammad Yusuf. Imagination of Sufism. -Tashkent: Shark, 2012.

7. Komil Yilmaz. Sufism and sects. Istanbul. 1997. -Page. 20-22

8. Bartels E.S. "Sufism and Sufi literature" Moscow: 1965. page. 39.

9. Hamidkhan Islami. Sultan ul-Arifin Khoja Ahmad Yassavi. Tashkent .: Academy of Sciences of the Republic of Uzbekistan "Fan" publishing house. 2005. -Page.25. www.ziyouz.com library

10. Ibrahim Haqqul. Ahmad Yassavi. - Tashkent .: Gafur Gulom Publishing House of Literature and Art. 2001. -Page. 10.

11. Ahmad Yassavi. "Hikmatlar" .- Tashkent .: G. Gulom Publishing House of Literature and Art. 1991. -Page. 51.

12. Hasaniy $M$, Razzokova $M$, Khojagan sect and Khoja Hasan Andoqi. - Tashkent .: Publishing House of the Republican Scientific and Educational Center named after Imam Bukhari. 2003. -Page. 3. 